\title{
Incidental finding of malignant transformation of dermoid cyst in squamous cell carcinoma: a case report
}

\author{
Sanjay Badesara ${ }^{1 *}$, Rambeer Singh $^{2}$, Satya Prakash $^{3}$
}

\author{
${ }^{1}$ Department of Surgical Oncology, Delhi State Cancer Institute, Delhi, India \\ ${ }^{2}$ Department of Surgery, Pt B.D. Sharma, PGIMS, Rohtak, Haryana, India \\ ${ }^{3}$ Department of Urology, Army hospital Research and Referral, New Delhi, India
}

Received: 22 December 2020

Accepted: 08 January 2021

\author{
*Correspondence: \\ Dr. Sanjay Badesara, \\ E-mail: drsanjay908badesara@gmail.com
}

Copyright: (C) the author(s), publisher and licensee Medip Academy. This is an open-access article distributed under the terms of the Creative Commons Attribution Non-Commercial License, which permits unrestricted non-commercial use, distribution, and reproduction in any medium, provided the original work is properly cited.

\begin{abstract}
Benign cystic mature teratomas are the most common variant of ovarian germ cell tumors (OGCTs) accounting for more than 95 percent of ovarian teratomas and is almost invariably benign. Malignant transformation occurs in 0.2 to 2 percent of dermoid and comprise of 2.9 percent of all malignant OGCTs. A 58-year-old postmenopausal lady presented with adnexal mass. Her CA-125 was $123 \mathrm{U} / \mathrm{ml}$, CEA-1.71. Ascitic fluid cytology was negative for malignancy. CT scan showed left adnexal mass $5.8 \times 5.2 \mathrm{~cm}$ and ascites was present. After surgical staging, a diagnosis of moderately differentiated squamous cell carcinoma in dermoid cyst of left ovary FIGO stage 1C2 was made.
\end{abstract}

Keywords: Mature cystic teratoma, Dermoid cyst, Malignant transformation

\section{INTRODUCTION}

Benign cystic mature teratomas (dermoid cyst) are the most common variant of ovarian germ cell tumors (OGCTs) accounting for more than 95 percent of ovarian teratomas and are almost invariably benign. ${ }^{1}$ Dermoid cysts are most commonly diagnosed during reproductive period, but malignant transformation usually occurs in post-menopausal women. ${ }^{2,3}$ Some malignant OGCTs develop when components of dermoid cysts develop into somatic malignant neoplasm. Malignant transformation occurs in 0.2 to 2 percent of dermoid cysts and comprise of 2.9 percent of all malignant OGCTs.,5 Of all, squamous cell carcinoma arising from the ectoderm, is the most common secondary neoplasm. ${ }^{2}$ The index case highlights the development of squamous cell carcinoma in dermoid cyst.

\section{CASE REPORT}

A 58-year-old postmenopausal lady with P2L2A1 presented with adnexal mass with comorbidities of diabetes mellitus and hypothyroidism. On examination of abdomen, gross ascites could be detected, but no mass was felt. Per speculum examination was unremarkable. Bimanual pelvic examination showed left fornix fullness and anteverted, firm, mobile, atrophic uterus. Per rectal examination revealed free rectal mucosa and the cystic mass was felt. There was no supraclavicular lymphadenopathy. Both breasts and axilla were normal on palpation. There was no inguinal lymphadenopathy. The CA-125 and serum CEA were $123 \mathrm{U} / \mathrm{ml}$ and 1.71 $\mathrm{ng} / \mathrm{ml}$ respectively. Ascitic fluid cytology was negative for malignancy. Computed tomography scan showed left adnexal mass of $5.8 \times 5.2 \mathrm{~cm}$ with no obvious areas of haemorrhage, necrosis, and ascites or lymphadenopathy.

Staging laparotomy for the adnexal mass was plannedleft side salpingo-oophorectomy was done and frozen section reported dermoid cyst with squamous cell carcinoma differentiation. The total abdominal hysterectomy with right salphingo-oophorectomy, bilateral pelvic lymphadenectomy, para-aortic lymphadenectomy with infra-coloic omentectomy were done. Postoperative histopathology revealed moderately differentiated squamous cell carcinoma in dermoid cyst 
left ovary (Figure 1) immuno-histochemistry (IHC) P63 positive (Figure 2) FIGO stage IC2. Adjuvant chemotherapy in the form of paclitaxel and carboplatin of six cycles were given. She is currently disease free at a follow up of 10 months.

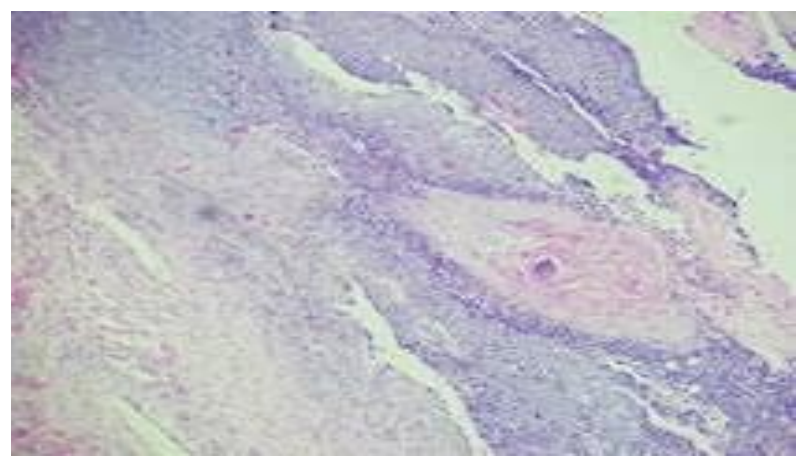

Figure 1: Moderately differentiated squamous cell carcinoma in dermoid cyst.

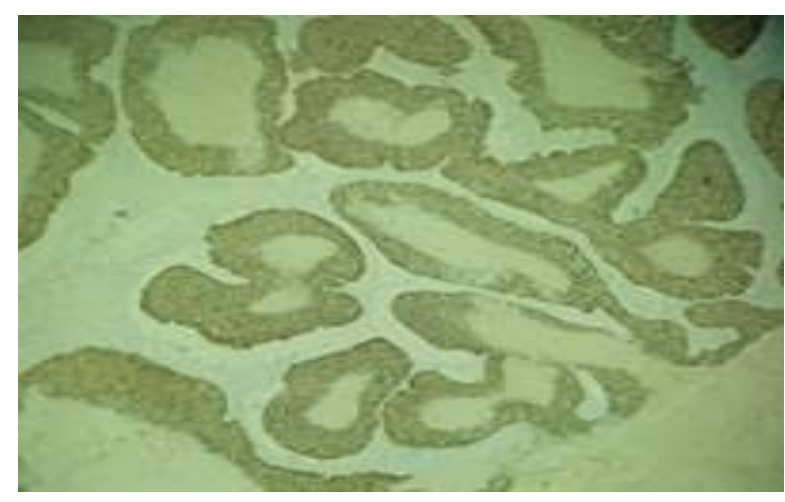

Figure 2: Immuno-histochemistry P63 positive.

\section{DISCUSSION}

Malignant transformation occurs in 1 to 2 percent of dermoids and comprises of 2.9 percent of all malignant ovarian germ cell tumors. ${ }^{6}$ Dermoid cysts are most commonly diagnosed during reproductive period. But malignant transformation usually occurs in postmenopausal women. ${ }^{2,3} 80 \%$ of malignant transformations are of squamous cell histopathology cases. ${ }^{2}$

Though in present case, size of left adnexal mass was $5.8 \times 5.2 \mathrm{~cm}$, but Kikkawa and Chen et al found that tumor size of more than $10 \mathrm{~cm}$ had higher chances of malignant transformations while Hackethal et al reported that malignant transformation is more frequent in lesions showing areas of haemorrhage and necrosis. ${ }^{2}$

Emoto et al observed that intra-tumoral blood vessel resistance may help distinguishing between benign or malignant teratomas, Mori et al predicted-on CT scan that if angle between cyst wall and soft tissue border is obtuse, it may hint towards malignancy. ${ }^{9,10}$ While Park et al, on MRI found that transmural solid tissue extension involving nearby tissues is indicative of malignancy. ${ }^{11}$
Tazo et al looked into the role of frozen section which can give an evidence of histopathology. ${ }^{12}$ Subbian et al found that frozen section is more accurate for diagnosing malignant or benign lesions with low accuracy in mucinous and borderline. ${ }^{13}$

Rathore reported that 8 out 230 cases had malignant transformation with 4 out of 8 had squamous histopathology. Transitional cell carcinoma, adenocarcinoma and malignant melanoma were found in two and one each respectively. The mean age of patients for malignant transformation was $44.2 \pm 8.94$ years. It was higher than mature cystic group $32.5 \pm 13.11$ years. ${ }^{14}$

The index patient was given adjuvant chemotherapy in the form of paclitaxel and carboplatin-six cycles. Goudeli et al advocated adjuvant chemotherapy because of poor prognosis and high recurrence rate. ${ }^{15}$ Hackthal et al reported a median survival of 25.2 months and 57.1 months in 119 patients with squamous cell carcinoma of teratomal origin with non-alkylating agents and with alkylating agents respectively. $^{2} \mathrm{He}$ reported that radiotherapy was not beneficial. 5-year survival is inversely associated with squamous cell carcinoma (SCC) antigen, CA125 levels. In the index patient, CA 125 was $123 \mathrm{U} / \mathrm{ml}$ and SCC antigen was not done. ${ }^{2}$

Cooke et al observed that 20 out of 25 patients with squamous cell carcinoma arising from ovary had mutation in TP53 and was associated with better prognosis while 52\% PIK3CA and 44\% had CDKN2A mutations. $^{16}$

\section{CONCLUSION}

The case reported was a rare occurrence of a dermoid cyst which could not be diagnosed preoperatively or even suspected. The intra-operative frozen section study revealed the surprise diagnosis. There is no guideline on management of such rare cases and hence the surgery involved the staging laparotomy for epithelial ovarian cancer. The case is presented for its rarity and discussion on its management and prognosis from a detailed review of literature. In known case of dermoid cyst, if size is more than $10 \mathrm{~cm}$, the risk of malignant transformation had to be thought of. Malignant changes in dermoid cyst most of times diagnosed during frozen section or final histopathology but may be predicted early by radiological imaging.

\section{ACKNOWLEDGMENTS}

Authors would like to thank participant who consented to be a part of our case report and the institution for their kind cooperation in the making of this manuscript and its submission.

Funding: No funding sources

Conflict of interest: None declared

Ethical approval: Not required 


\section{REFERENCES}

1. Ayhan A, Bukulmez O, Genc C, Karamursel BS, Ayhan A. Mature cystic teratomas of the ovary: case series from one institution over 34 years. Eur J Obstet Gynecol Reprod Biol. 2000;88:153.

2. Hackethal A, Brueggmann D, Bohlmann MK, Franke FE, Tinneberg HR, Münstedt K. Squamouscell carcinoma in mature cystic teratoma of the ovary: Systematic review and analysis of the published data. Lancet Oncol. 2008;9:1173.

3. Rim SY, Kim SM, Choi HS. Malignant transformation of ovarian mature cystic teratomas. Int J Gynecol. Cancer. 2006;16:140-44.

4. Westhoff C, Pike M, Vessey M. Benign ovarian teratomas: a population- based case -control study. Br J Cancer. 1998;58-93.

5. Smith HO, Berwick M, Verschraegen CF, Wiggins C, Lansing L, Muller CY et al. Incidence and survival rates for female malignant germ cell tumors. Obstet Gynecol 2006;107:1075.

6. Avcı S, Selcukbiricik F, Bilici A, Ozkan G, Ozagarı A, Borlu F. Case reports squamous cell carcinoma arising in a mature cystic teratoma. Case Rep Obstet Gynecol. 2012;314535.

7. Kikkawa F, Ishikawa H, Tamakoshi K, Nawa A, Suganuma N, Tomoda Y. Squamous cell carcinoma arising from mature cystic teratoma of the ovary: a clinicopathologic analysis. Obstet Gynecol. 1997;89(6):1017-22.

8. Chen RJ, Chen KY, Chang TC, Sheu BC, Chow SN, Huang SC. Prognosis and treatment of squamous cell carcinoma from a mature cystic teratoma of the ovary. J Formosan Med Asso. 2008;107(11):857-68.

9. Emoto M, Obama H, Horiuchi S, Miyakawa T, Kawarabayashi T. Transvaginal color Doppler ultrasonic characterization of benign and malignant ovarian cystic teratomas and comparison with serum squamous cell carcinoma antigen. Cancer. 2000;88(10):2298-304.
10. Mori Y, Nishii H, Takabe K, Shinozaki H, Matsumoto N, Suzuki K et al. Preoperative diagnosis of malignant transformation arising from mature cystic teratomas of the ovary. Gynecol Oncol. 2000;90:338-41.

11. Park SB, Kim JK, Kim KR, Cho KS. Preoperative diagnosis of mature cystic teratoma with malignant transformation: analysis of imaging findings and clinical and laboratory data. Arch Gynecol Obstet. 2007;275:25-31.

12. Tazo Y, Yoshimura Y, Shoda T, Kyushima N, Okada T, Yamazaki H. Relevance of frozen sections and serum markers in invasive squamous cell carcinoma arising from ovarian mature cystic teratoma: two case reports. J Med Case Rep. 2016;10:20.

13. Subbian A, Devi UK, Bafna UD. Accuracy rate of frozen section studies in ovarian cancers: A regional cancer institute experience. Indian $\mathbf{J}$ Cancer. 2013;50:302-5.

14. Rathore R, Sharma S, Agarwal S. Malignant transformation in mature cystic teratoma of the ovary:a retrospective study of eight cases and review of literature. Menopause Rev. 2018;17(2):63-8.

15. Goudeli C, Varytimiadi A, Koufopoulos N, Syrios J, Terzakis E. An ovarian mature cystic teratoma evolving in squamous cell carcinoma: A case report and review of the literature. Gynecologic Oncology Rep. 2017;19:27-30.

16. Cooke SL, Ennis D, Evers L, Dowson S, Chan MY, Paul J et al. The Driver Mutational Landscape of Ovarian Squamous Cell Carcinomas Arising in Mature Cystic Teratoma. Clin Cancer Res. 2017;23(24):7633-40.

Cite this article as: Badesara S, Singh R, Prakash S. Incidental finding of malignant transformation of dermoid cyst in squamous cell carcinoma: a case report. Int J Reprod Contracept Obstet Gynecol 2021;10:755-7. 